\title{
Teachers' Intercultural Sensitivity Towards Pupils Belonging to a Cultural Minority: A Quantitative Research in the Prefecture of Aitoloakarnania, Greece
}

\author{
Zoe karanikola, Stathis Balias \\ University of Patras, Department of Education and Early Childhood Education, Rion, Greece
}

Email address:

gzdanias@yahoo.gr (Z. karanikola),balias@upatras.gr (S. Balias)

To cite this article:

Zoe karanikola, Stathis Balias. Teachers' Intercultural Sensitivity Towards Pupils Belonging to a Cultural Minority: A Quantitative Research in the Prefecture of Aitoloakarnania, Greece. International Journal of Elementary Education. Vol. 4, No. 2, 2015, pp. 35-40.

doi: $10.11648 /$ j.ijeedu.20150402.13

\begin{abstract}
This paper presents the results of a quantitative research conducted in the Aitoloakarnania Prefecture in order to investigate whether Primary Education teachers are sensitive towards pupils belonging to a cultural minority and whether their sensitivity is influenced by gender, time of graduation, education level, training, their experience in culturally diverse classes and their direct or indirect personal migration experience. The research results showed that the orientation of teachers seems to be at the stage of acceptance, the first of the three ethnorelative stages of Bennett, which reflects their ability to perceive diversity, to be open towards it, respect it and express curiosity to learn more things.
\end{abstract}

Keywords: Diversity, Intercultural Education, Legislation, Nationalism, Intercultural Sensitivity

\section{Introduction}

The problem of co-existence of culturally different populations is very intense in Greece since over the last 40 years it has become a host country for immigrants, mainly from the Balkans and Eastern Europe. According to the last census (National Statistical Authority, 2011), the percentage of aliens residing permanently in Greece is $8.34 \%$, of which $52.7 \%$ come from Albania. With regard to the pupil population, the number of alien pupils approaches $6 \%$ of primary school pupils (Cyprianos, 2008).

In order to provide more effective management of diversity, the Greek state adopted international and European conventions, ratified by the respective laws, enriched the legal framework, implementing several models and management strategies of diversity, proceeding to changes of the curricula, to the writing of new school books and to the implementation of new study programs. In addition, the recent Presidential Decree for the Evaluation of Teachers (Sheet No. 240, $5 / 11 / 2013$ ) makes a particular reference to the ability of teachers managing cultural diversity.

Thus, on the one hand there is a strong legislative framework, influenced by the respective international one, which promotes universal principles and fundamental human rights for all pupils and, on the other hand, there is a strong emphasis on the need to develop and strengthen national identity which is threatened. This leads to practices that favor phenomena such as racism, xenophobia, prejudice and stereotypes (Keddie, 2012). Research done by Eurobarometer (2003) showed that in Greece many racist and nationalist manifestations exist, bringing the percentage of xenophobia and racism to the top of the European ranking there, where $87.5 \%$ of Greeks have a negative image of immigrants (Eurobarometer, 2007). Furthermore, Greek citizens regard that there are too many immigrants in their country, (Eurobarometer, 2011), emphasizing that the most frequent form of discrimination in Greece regards nationality (Eurobarometer, 2012).

In this context, the role of intercultural education is of major importance as it is an educational model of managing the nation's cultural diversity and is directly associated with the promotion of human rights, since at its heart there are vulnerable groups and the promotion of equal rights in both education and society (Rolandi-Ricci, 1986). However, according to international literature, the promotion of intercultural education principles is greatly affected by the teacher (Keddie, 2012; Dimmock and Walker, 2005; Irvine, 2003). Are teachers sensitive towards diversity? Is nationalism a hindrance to their effective function in class or not? 


\section{Theoretical Framework}

\subsection{Diversity: Definition}

Diversity is an inescapable fact of our social coexistence. On a general superficial level, it concerns every personal, physical or demographic characteristic (skin, gender, origin) (Ely and Thomas, 2001: 230), while on a deeper level it concerns attitudes, values and beliefs (Harrison et al, 1998). Language, ethnicity, religion and culture are the most renowned axes around which diversity develops and in this sense it is a fundamental element of individual existence and personal experience, since it includes the worldview, the system of values as well as the attitudes and beliefs of the group to which a person belongs (Adler, 2002). Cultural diversity almost always occurs in conjunction with one or more of the aforementioned categories and its relationship to the other types of diversity is a shell/content relationship and is defined as "the manifold ways in which the cultures of groups and societies find expression" (UNESCO, 2005, Article 4.1).

The definitions of Hoffman and Moll mainly approach cultural minorities. Thus, according to Hoffman (1997), almost every definition of diversity focuses on the experiences of minorities that were historically mistreated by education and socioeconomic structures, while Moll defines diversity in relation to racial, cultural or class differences noting that its management at school is a major educational issue of the $21 \mathrm{st}$ century (op. cit. Boethel, 2003). Furthermore, according to Luhabe (2001), diversity in itself constitutes a new culture of human behavior, which honors people wherever they are, whatever they know, irrespective of how they have gained knowledge and how they implement it (op. cit. Parvis, 2013).

\subsection{Greek Legal Framework Regarding Cultural Diversity and its Implementation}

By mainly studying the Greek legislation for the period 1996-2012, we find that there is a plethora of laws, presidential decrees, circulars and ministerial decisions regarding cultural diversity, through which cultural multiformity is promoted. This is a springboard for sustainable development of peoples; intangible cultural heritage is protected and reinforced while recognition as well as protection of minority rights are encouraged. Legal texts emphasize on the Education of Aliens and the promotion of Human Rights, mainly through the National Commission for Human Rights (1998).

The National Commission for Human Rights (NCHR) was established by Law 2667/1998 and is an Advisory Body of the State which concentrates on issues relating to the protection of Human Rights. According to its annual reports (from 2000 to 2012), intercultural education in Greek schools is primarily promoted through compensatory measures and the implementation of programs, most of which are effectuated in collaboration with certain Universities. These programs promote principles such as equality, elimination of discrimination, tolerance, social justice and mutual respect between peoples and cultures. With regard to the training of teachers, the aim is information, awareness, management of problems in the classroom and their participation in experimental workshops.

\subsection{National Identity and Nationalism}

The acceptance of diversity is often contrary to the very nature of the Nation-state and national identity, having as a result cultural diversity being treated as a national crisis (Battle Vold et al., 2003). But, what is national identity?

According to Hall (1998), national identity is experienced as part of our biological nature, while according to Basch et al. (1994), it is fundamental and natural (op. cit. Banks, 2001: 2). Stuart Hall (2000) mentions that identities work as points of identification and adherence because of their ability to exclude what is considered foreign, so we structure a sense of what we are through the understanding of what we are not and therefore we always invoke practices of inclusion and exclusion (op. cit. Reay, 2003).

Nationalism is considered a symptom of national identity. According to Hannaford (1996), Omi and Winant, (1994), it always involves racist and anti-Semitic elements (op. cit. Banks, 2004), which can be detected in procedures, attitudes, behaviors and puts minority groups at a disadvantage (Osler and Starkey, 2000). Consequently, the co-existence of different cultural and ethnic groups is difficult. Even in cases where the relevant legislative regulations favor cultural interaction, this is hardly applicable. The foreigner is often welcomed only verbally but will never be allowed to denature the structures of the host society. The foreigner, the unknown is acclaimed as a "devilish figure", as Pierre-André Taguieff says (op. cit. Schnapper and Allemand, 2006: 57).

The Greek national identity and the respective ethnocentric nationalism create very favorable conditions for the Greek society to be permeated by strong xenophobic and racist elements that exceed the average of the European countries (Karakatsanis and Swarts, 2007). Furthermore, it has a decisive influence on the educational system and makes it intolerant towards culturally different pupils (Sotirelis, 1993).

Consequently, the question arises whether Greek nationalism can affect the attitude of teachers towards culturally different pupils.

\subsection{Intercultural Sensitivity of Teachers}

The effective functioning of teachers in the classroom is internationally described by terms such as intercultural sensitivity, intercultural competence and intercultural readiness. Intercultural sensitivity is one's ability to discern and experience relevant cultural differences and is a key prerequisite for intercultural competence (Hammer et al, 2003, Chen and Starosta, 2000, Villegas and Lucas, 2007, Bhawuk and Brislin, 1992). Intercultural competence refers to an individual's overall ability to go beyond ethnocentrism, to evaluate other cultures, to adopt the right attitude towards other cultures (Robins et al., 2006; Davis and Cho, 2005; Bennett and Allen, 2003; Ladson-Billings, 2001), but also to 
effectively teach pupils coming from different cultures (Diller and Moulle, 2005).

\section{Research Methodology}

\subsection{Research Aim}

This work comes to examine whether or not primary teachers are sensitive towards diversity and whether their sensitivity is affected by their gender, the period of graduation, their study level, their professional development, their intercultural experience and the migration experience they have themselves (direct) or as a family member (indirect).

\subsection{Research Sample}

The research was conducted in the Prefecture of Aitolokarnania, one of the largest in Greece. In 2011-2012, in a total of 13.445 pupils enrolled in public elementary schools of the Prefecture, 890 are aliens (6.61\%). The total number of teachers employed in this Prefecture is 1.594, of which 799 are men and 795 women. Those teachers work in the four divisions of the Prefecture whose main premises are located in the cities of Messolonghi, Nafpaktos, Agrinio and Amfilochia.

Our sample was drawn from a list of the Directorate of Primary Education containing the 128 schools of the Prefecture, where alien pupils were enrolled. The number of alien pupils in these schools ranged from 1 to 49 , while schools had from 2 to 12 teachers. The sample of the research is representative and includes 50 different primary schools. A total of 400 questionnaires were distributed, of which 318 were answered and returned producing a response rate of $79.5 \%$. The questionnaires were filled out via self-completion and were mainly sent by mail.

\subsection{Structure of the Questionnaire}

Each questionnaire consists of 34 sentences (a five-Likert scale), regarding attitudes /dispositions teachers have towards cultural diversity.

The Development Model of Intercultural Sensitivity (DMIS) by Bennett (1993) (table 1) consists of the basic theoretical model on which the suggestions relevant to the attitudes /dispositions of teachers towards heterogeneity is built. The choice of this theoretical model occurred mainly because it examines the effect of nationalism on intercultural sensitivity of individuals. It constitutes a model of cognitive development on which the personal construct theory and radical constructivism is based. It was developed as an explanation to the way people interpret cultural differences. This emerged after years of empirical observation of individuals who took part in intercultural workshops, subjects, exchanges and post-graduate programs. It consists of six stages, three ethnocentric (the culture of each individual is the central world view) and three ethnorelative (the culture of each individual is one of many equally valid worldviews). Denial, defense and minimization of cultural differences are referred to as ethnocentric and acceptance, while adaption and integration are referred to as ethnorelative. In this particular questionnaire, integration was not used, because it concerns societies which are particularly pluralistic.

Table 1. Stages of Developmental Model of Intercultural Sensitivity, Bennett, 1993.

\begin{tabular}{|c|c|c|c|c|c|}
\hline \multicolumn{6}{|c|}{$\begin{array}{l}\text { Developmental model of intercultural sensitivity (dmis) } \\
\text { Experience of difference }\end{array}$} \\
\hline Ethn & ges & $\longrightarrow$ & Ethno & & \\
\hline Denial & Defense & Minimization & Acceptance & Adaptation & Integration \\
\hline
\end{tabular}

The Intercultural Development Inventory (IDI) (2001) was developed by Dr. Mitchell Hammer and Dr. Milton Bennett; it is based on DMIS and consists of a 50-item instrument, psychometrically valid, which measures the cultural sensitivity of individuals. The particular instrument is used in various fields and places. I, however, wanted to focus on the area of education. For this reason, I did not use all of it, but only sample items and key-words concerning education. Furthermore, to form these suggestions for each of the five levels of DMIS, I studied some other scales, which focus on nationalism and its effect on inter-cultural competence and communication. Such scales are the Worldmindedness Scale (Sampson \& Smith, 1957), the Global Mindedness Scale (Hett, 1993), the GENE Scale (Neuliep and McCroskey, 1977) and the Intercultural Sensitivity Scale (Chen and Starosta, 1996, 2000).

The Worldmindedness Scale (Sampson \& Smith, 1957) emerged after World War II and was used in many fields including business (Crawford \& Lamb, Jr., 1982; O'Leary, 2002; Schell, Sherritt, Lewis, \& Mansfield, 1986), education (Barnes \& Curlettee, 1982; Bloater , 1993; Douglas
\&Jones-Rikkers, 2000; Garrison, 1961;Marjoribanks, 1981; Parker, Glenn, Mizoue, Meriwether \& Gardner, 1997; Paul, 1966), negotiation behavior (Dittloff \& Harris, 1996) and religious studies (Keene, 1967; Sharp, 1988, 1990) (op. cit. Vassar, 2006). In total, it includes 32 items and relates to six dimensions: religion, immigration, government, economics, patriotism, race, education and war. In this questionnaire, an unedited item as well as three altered ones were used.

The Global Mindedness Scale (Hett, 1993) recommends a more modern five-point scale (Likert) with thirty items and is used to ascertain the way someone sees themselves not only in relation to the global community but also how they feel themselves as a member of this community. It consists of five dimensions: responsibility, cultural pluralism, efficacy, Globalcentrism and Interconnectedness. In this questionnaire, one unedited and one altered item were used.

The GENE (Generalized Ethnocentrism) Scale of Neuliep and McCroskey (1997) recommends a scale which determines ethnocentrism and is based on definitions and views developed by Hewstone and Ward (1985), Islam and Hewstone (1993), Segall (1979), Summer (1906) and Lukens 
(1978), according to whom nationalism is linked with the pride and vanity of an ethnic group, with feelings of hostility and fear towards strangers as well as indifference and avoidance as referred to in Bennett's stage of denial. It consists of twenty-one items and can be used by anyone, regardless of cultural origin. It has high validity and is considered to be reliable. In this questionnaire, only one altered item was used.

The scale of Chen \& Starosa (2000) concerns cultural attitudes and behaviors and consists of twenty-four items categorized into five areas: Intercultural Engagement, Interaction Confidence, Interaction Enjoyment and Interaction Attentiveness. Its validity has been demonstrated in different cultural environments (Wolfgang, Mollenberg, Chen, 2000). In this questionnaire and from this scale two edited items were used.

\subsection{Data Analysis}

The questionnaires were processed by SPSS 18. As far as the reliability of the scale, the Cronbach's Alpha, the statistical index of internal consistency, as a whole was 0.866 , which represents satisfactory quality of the measurement.

\subsection{Research Results}

The results can be separated into 2 categories: demographic data and Scale of Intercultural Sensitivity.

Regarding the demographic data, 123 participants were male and 195 female, 170 participants graduated before 1996 and 148 after 1996 (the 2413/1996 legislation was the first institutional measure taken towards the direction of intercultural education). In addition, 129 participants graduated from 2-year Faculties of Education (Pedagogical Academies), while 189 graduated from 4-year Pedagogical Faculties. 75 participants have post graduate studies. $57.9 \%$ of the participants have attended subjects relating to Intercultural Education and Diversity during their basic studies, while $32.1 \%$ of the participants have attended some seminars. $62.9 \%$ have average experience with foreign students, while 85 participants $(25 \%)$ have direct or indirect migration experience.

Regarding the Scale of Intercultural Sensitivity, according to the research results (which were based on Hammer's psychometric instrument IDI), the participants are at an ethnorelative stage, the one of the Acceptance of difference (table 2). Gender, time of graduation, basic level of studies and the migration experience they personally have do not seem to affect the results of the scale. However, post-graduate studies seem to significantly influence the subscales of Minimization and Adaptation. In addition, the experience teachers have with students of different cultural background significantly affects the results of the scale.

Table 2. Teachers' mean total scale score (based on IDI).

\begin{tabular}{lllllll}
\hline \multicolumn{2}{l}{ teachers' mean scale skor } \\
\hline Denial & Defense & Minimization & Acceptance & \multicolumn{2}{c}{ Adaptation } \\
\hline \\
34 & 57 & 79 & 102 & 135.79 & & \\
\hline
\end{tabular}

\section{Discussion}

The research results show that the orientation of teachers seems to be at the stage of acceptance, the first of the three ethnorelative stages of Bennett, which reflects their ability to perceive diversity, to be open towards it, respect it and express curiosity to learn more things. The recognition of alternative cultural behavior implies the acceptance of deeper cultural differences such as language, non-verbal communication, modes of communicating and thinking. This orientation is a characteristic of the policies recognizing and preserving cultural diversity and protecting fundamental rights. Issues related to their defense against diversity, the minimization of cultural differences, the acceptance and the adaptation of their behavior seem to be resolved.

Gender, obtainment of a degree and basic educational level does not affect the levels of the scale and the subscales. Similarly, a research by Fretheim (2007) and Westrick and Yuen (2007) did not show that intercultural sensitivity differs in relation to gender. However, statistically, additional studies significantly affect minimization and adaptation subscales, whereas those with additional studies show greater ability to resolve such issues than those without additional studies. A research by Gorham(2001) and Holcomb-McCoy (2005) showed that teachers with higher levels of intercultural education demonstrated more respect for cultural diversity, more readiness and better ability to overcome prejudices (op. cit. Henkin et al, 2008: 101-109). Similarly, researches by Westrick and Yuen (2007), Helmer (2007) and Fretheim (2007) showed that there is a connection between educational level and intercultural sensitivity.

Also, experience with alien pupils significantly seems to affect both the scales and subscales of denial and defense. Teachers having extensive experience with alien pupils have, to a greater extent, resolved issues related to denial and defense and have a higher score than teachers with little or moderate experience. According to Zeichner (1993), experience in multicultural schools is a cornerstone for the implementation of intercultural education (op. cit. Battle Vold et al, 2003). In contrast, migration experience does not seem to play an important role in the formation of levels in the aforementioned scales, although other researches have shown that there is a significant correlation or affinity between intercultural sensitivity and experience of living in other cultures (Westrick and Yuen, 2007).

\section{Conclusion}

The results show that teachers are not indifferent to diversity. They seem to have accepted it and ethnocentrism is not an obstacle to intercultural communication. Not only are they curious to learn more things about minority groups and show willingness to interact with them, but they are also open to new experiences. In educational settings, teachers try to diversify the curriculum to be more representative of a broad range of cultural perspectives (Hammer et al, 2003).

Consequently, the policies that have been implemented in 
Greece in recent years and the consequential changes they have brought in new Curricula and new schoolbooks, in which diversity is taken into account, have affected teachers as well, all of whom appear sensitized at least. These policies follow the liberal approach and, more specifically, the liberal plural limited integration, where diversity both in society and within school is recognized and reflected in the formal and informal curriculum (McGlynn, 2013).

However, there is still more to be done, in order to move on to the next stage of adaptation, whose dominant dispositions are empathy, openness, flexibility, tolerance,responsibility, creativity and commitment to social justice. In addition, in this stage there is a cognitive frame shifting as well as a behavioral code shifting, where teachers recognize the added value of having more than one cultural perspective as well as a broad repertoire of behavior, allowing you to act outside your own culture. Besides, teachers feel safe in the presence of culturally-different students, who behave and communicate effectively in a variety of other cultures (Hammer et al 2003).

In order to develop adaptation competence, teachers need better instruction, need to be more informed on diversity issues and need to participate more in programs and actions, because in this way they will change their attitude and approach towards managing culturally-diverse pupils. Moreover, teachers will realize that school is not a neutral area, but an area with important issues of justice which should be addressed. Additionally, a teacher's knowledge on diversity needs to be derived from contact and co-operation with the community (Garcia et al, 2010), because this is how the ability to empathize with their experience develops more (Alred, 2003). Cooperation and constructive dialogue between all those involved in the educational process will help to more accurately address issues related to diversity.

The scales, despite the endogenous and exogenous weaknesses, constitute instrumentation and research, which allows the shaping of our value judgments (Babbie, 2011). The sample used in this research was representative and the Cronbach's Alpha for the scale as a whole was satisfactory.However, this particulate scale, which was designed as an instrument to measure teachers' sensitivity towards cultural diversity, has never been used before. It is suggested that it should be tested in some other similar cases. In addition, a qualitative research can complement and enrich this qualitative research study, as the comparison of the two seems to create huge interest and new implications.

\section{References}

[1] Adler, N. (2002) International Dimensions of Organizational Behavior. Cincinnati: South-Western College Publishing.

[2] Alred, G. (2003) 'Becoming a "Better Stranger": A Therapeutic Perspective on Intercultural Experience and/ as Education'. In G. Alred, M. Byram and M. Fleming (eds), Intercultural Experience and Education. Great Britain: Cromwell Press LTD.
[3] Babbie, E. (2011) Introduction to social research. Wadsworth, Cengage Larning.

[4] Banks, J.A. (2001). Citizenship Education and Diversity: Implications for Teacher Education, Journal of Teacher Education January, 52: 5-16.

[5] Banks, J. P. (2004) Introduction to Multicultural Education. Athens: Papazisi. [in Greek].

[6] Battle Vold, E., Ramsey, P.G. and Williams, L.R.(2003) Multicultural education: A Source Book. N.Y.: RoutledgeFalmer.

[7] Bennett, J.M., Bennett, M.J. and Allen, W. (2003) 'Developing Intercultural Competence in the Language Classroom'. In D.L. Lange and R.M. Paige (eds), Culture as the core: Perspectives on culture in second language learning. Greenwich, CT: Information Age Publishing.

[8] Boethel, M. (2003) Diversity. School, Family \& Community Connections. Annual Synthesis. Austin, Texas: SEDL.

[9] Chen, G.M. and Starosta, W.J. (2000) 'The Development and Validation of the Intercultural Communication Sensitivity Scale'. Human Communication, 3, 1-15.

[10] Chen, G.M. and Starosta, W.J. (1996) 'Intercultural Communication Competence: a synthesis'. Communication Yearbook, 19, 353-383.

[11] Cyprianos, P. (2008) 'Diversity, Educational Inequalities, and Educators'. In E. Makri - Botsari (ed.) Management Issues of Classroom

ProblemsII.http://www.pi-schools.gr/programs/sxoltaxi/tomos B.pdf.

[12] Davis, N. and Cho, M.O. (2005) 'Intercultural competence for future leaders of educational technology and its evaluation'. Interactive Education Multimedia, 10, 1-22.

[13] Diller, J.V.(2011) Cultural diversity. A Primer for the Human Services.Pacific Grove, CA: Brooks Cole/ Cengage.

[14] Diller, J.V. and Moule, J. (2005) Cultural Competence: A primer for educators. Belmont, CA: Thomson Wadsworth.

[15] Dimmock, C. and Walker, A. (2005) Educational Leadership. Culture and Diversity. London: Sage Publications.

[16] Ely, R.J. and Thomas, D.A. (2001) 'Cultural Diversity at Work: The Effects of Diversity Perspectives on Work Group Processes and Outcomes'. Administrative Science Quarterly, 46 (2), 229-273.

[17] Eurobarometer (2012) Discrimination in the EE.http://ec.europa.eu/public_opinion.

[18] Eurobarometer (2011) Migrant Integration. http://ec.europa.eu/public_opinion/archives/quali/ql_5969_mi grant_en.pdf.

[19] Eurobarometer 67 (2007) Public Opinion in EE. http://ec.europa.eu/public_opinion/archives/eb/eb67/eb67_en. pdf. 
[20] Eurobarometer (2003) Majority populations' attitudes towards migrants and minorities.http://fra.europa.eu/sites/default/files/fra uploads/1 48-Report-1.pdf.

[21] Frethein, A.M. (2007) 'Assessing the intercultural sensitivity of educators in an American International School'. (Doctoral dissertation, University of Minessota). Dissertation Abstracts International, 68 (12) (UMI No 3292934).

[22] Garcia, E., Arias, M.D., Murri, H., and Serna, C. (2010) 'Developing Responsive Teachers: a challenge for a demographic reality'. Journal of teacher education, 61 (1/2) 132-142.

[23] Griggs, L.B. and Louw, L. (1995) Valuing Diversity: New tools for a new reality. N.Y.: McGraw - Hill.

[24] Hammer, M.R., Bennett, M.J. and Wiseman, R. (2003) 'Measuring Intercultural Sensitivity: the Intercultural Development Inventory'. International Journal of Intercultural Relations, 27, 421-443.

[25] Harrison, D.A., Price, K.H. and Bell, M.P. (1998) 'Beyond Relational Demography. Time and the effects of surface and deep level diversity on work group cohesion'. Academy of Management Journal, 41, 95-107.

[26] Henkin, R., Steinetz, A. and Carrillo, J. (2008) 'The Need for Diversity Education as Received by Pre-service Teachers'. Journal of the Scholarship of Teaching and Learning, 8, 101-109.

[27] Irvine, J.J. (2003) 'Educating Teachers for Diversity. Seeing with a cultural eye'. In J.A. Banks (ed.) Multicultural Education Series. Columbia University: Teachers College Press.

[28] Karakatsanis, N.M. and Swarts, J. (2007) 'Attitudes towards the xeno: Greece in comparative perspective'.Mediterranean Quarterly 18, 113-134.

[29] Keddie, A. (2012) Educating for Diversity and Social Justice. NY: Routledge.

[30] Ladson-Billings, G. (2001) Crossing over to Canaan: The journey of new teachers in diverse classrooms. San Francisco: Jossey-Bass.

[31] McGlynn, C. (2013) Intercultural Education. Learning from the Integrated Catholic and Protestant Schools in Northern Ireland in S. Goncalves, and M.A. Carpenter (eds) Research in Education. Diversity, Intercultural Encounters and Education. NY: Routledge.
[32] Neuliep, J. W. \& McCroskey, J. C. (1997). Development of a US and Generalized EthnocentrismScale. Communication Research Reports, 14, 385-398.

[33] Osler, A. and Starkey H. (2000) 'Citizenship, Human Rights and Cultural Diversity'.In A. Osler (ed.) Citizenship and Democracy in schools. Diversity, Identity, Equality. England: Trentham Print.

[34] Parvis, L. (2013) Understanding Cultural Diversity in Today's Complex World.USA: Lulu Press.

[35] Reay, D. (2003) 'Shifting class identities? Social class and the transition to higher education'. In C. Vincent (ed.) Social Justice, Education and Identity. London: RoutlegeFalmer.

[36] Robins, K.N., Lindsey, R.B., Lindsey, D.B., and Terrell, R.D. (2006) Culturally proficient instruction: A guide for people who teach. Thousand Oaks, CA: Corwin Press.

[37] Rolandi-Ricci, M. (1986). Intercultural Education and the Council of Europe. In C. Jones and K. Kimberley (eds), Intercultural Education: Concept, context Curriculum practice, Project No 7. Strasburg, Council for Cultural Co-operation, School Education Division.

[38] Schnapper, D. and Allemand, S. (2006) Judging Racism. Athens: Patakis. [in Greek].

[39] Sotirelis, K. (1993) Religion and Education according to the Constitution and the European Convention From catechism to polyphony. Athens: Sakkoula. [in Greek].

[40] UNESCO (2005) Convention on the Protection and Promotion of the Diversity of Cultural Expressions, Paris: UNESCO.http://portal.unesco.org/en/ev.php

[41] Vassar, M. (2006) An Internal Structure assessment of two measures of worldmindedness and their relationship with cultural pluralism, social distance, and social dominance orientation. Dissertation Abstracts International.

[42] Vilegas, A.M. and Lucas, T. (2002) Educating culturally responsive teachers: a coherent approach. Albanu, N.Y.: State University of New York Press.

[43] Westrick, J.M. and Yuen, C.Y.M. (2007) The intercultural sensitivity of secondary teachers in Hong Kong: A comparative study with implications for professional development. Intercultural Education, 18 (2), 129-145.

[44] Wolfgang, F., Mollenberg, A. Chen, G.M. (2000) Measuring Intercultural Sensitivity in Different Cultural Context.Technische Universitat Braunschweig. 